\title{
CHURCH REFORM OF PETER I: SOURCE STUDY ASPECT (ACCORDING TO THE MATERIALS OF THE VOLOGDA ARCHBISHOPS HOUSE OF ST. SOPHIA)
}

\author{
Nikita V. Bashnin \\ Saint Petersburg Institute of History of the Russian Academy of Sciences, Saint Petersburg, Russian Federation
}

Abstract. Introduction. The inventory of buildings and property are an accounting document. The largescale description of the lands and property of the spiritual patrimony of 1701-1705 carried out within the framework of the Church Reform of Peter I should be considered as a stage in the control of the state over the material welfare of the Church. Materials. Inventories of bishops houses and monasteries were found in the central and regional archives. A number of documents of the early $18^{\text {th }}$ century were published. Analysis. Different census takers carried out descriptions of the patrimonies of the Vologda Bishops house in five regions of the country, which indicates applying the uyezd by uyezd principle of the description of the regions. The comparison of the texts shows that census books of the patrimonies of the Vologda Bishops house of 1701-1702 were primary in relation to the census of economy (statements) of the Vologda Bishops house in 1702-1703. An inventory of the Bishops Treasury was also made. Results. The comparison of three censuses (patrimony, economy, treasury) gave state documents on the basis of which it was possible to make a complete picture of the economy and property of the Vologda house of St. Sophia. In this regard, a complete secularization of Church possessions actually took place, however it was not fully formalized legally.

Key words: history of the Russian Orthodox Church, Russian North, Vologda diocese, source study, Church reform of Peter the Great, census books, patrimony, secularization.

Citation. Bashnin N.V. Church Reform of Peter I: Source Study Aspect (According to the Materials of the Vologda Archbishops House of St. Sophia). Vestnik Volgogradskogo gosudarstvennogo universiteta. Seriya 4. Istoriya. Regionovedenie. Mezhdunarodnye otnosheniya [Science Journal of Volgograd State University. History. Area Studies. International Relations], 2020, vol. 25, no. 5, pp. 113-130. (in Russian). DOI: https://doi.org/10.15688/ jvolsu4.2020.5.10

\section{ЦЕРКОВНАЯ РЕФОРМА ПЕТРА І: ИСТОЧНИКОВЕДЧЕСКИЙ АСПЕКТ (ПО МАТЕРИАЛАМ ВОЛОГОДСКОГО АРХИЕРЕЙСКОГО ДОМА СВ. СОФИИ)}

\section{Никита Викторович Башнин}

Санкт-Петербургский институт истории РАН, г. Санкт-Петербург, Российская Федерация

Аннотация. Введение. Описи строений и имущества представляют собой учетный документ. Масштабное описание земель и имущества духовных вотчинников 1701-1705 гг., проведенное в рамках церковной реформы Петра I, следует рассматривать как этап в осуществлении контроля государства за материальным благосостоянием Церкви. Maтериальl. Описи архиерейских домов и монастырей выявлены в центральных и региональных архивах. Ряд документов начала XVIII в. опубликован. Анализ. Разные переписчики проводили описания вотчин Вологодского архиерейского дома в пяти регионах страны, что говорит о поуездном принципе описания. Сопоставление текстов показывает, что переписные книги вотчин 
Вологодского архиерейского дома 1701-1702 гг. были первичными по отношению к переписи хозяйства (ведомостям) Вологодского архиерейского дома 1702-1703 годов. Также была составлена опись архиерейской казны. Результаты. Сравнение трех переписей (вотчины, хозяйства, казны) дало государству документы, на основании которых можно было составить полное представление о хозяйстве и имуществе Вологодского дома Св. Софии. В связи с этим произошла фактически полная секуляризация церковных владений, но юридически полностью не оформленная.

Ключевые слова: история Русской Православной Церкви, Русский Север, Вологодская епархия, источниковедение, церковная реформа Петра I, переписные книги, вотчина, секуляризация.

Цитирование. Башнин Н. В. Церковная реформа Петра I: источниковедческий аспект (по материалам Вологодского архиерейского дома Св. Софии) // Вестник Волгоградского государственного университета. Серия 4, История. Регионоведение. Международные отношения. - 2020. - Т. 25, № 5. - С. 113-130. - DOI: https://doi.org/10.15688/jvolsu4.2020.5.10

Введение. Описи строений и имущества (отписные, описные, переписные книги) представляют собой особую группу источников, которые содержат сведения о духовной и материальной культуре средневекового общества и отражают имущественное положение церквей, монастырей и архиерейских кафедр. Они являются учетными документами, в которые в XVII в. часто включали не только описание икон, богослужебной утвари, книг и актов, но и сведения о вотчинных владениях духовных собственников [18, с. 7].

Дискуссия. В конце XIX в. Н.К. Никольский пришел к выводу, что после Стоглавого собора в целях контроля за церковным имуществом стали составлять монастырские описи. Ученый также отметил связь государственных кадастров и монастырских переписных книг. 3.В. Дмитриева подчеркнула, что наблюдения Н.К. Никольского о решающем значении Стоглавого собора в появлении монастырских описей не противоречат тому факту, что описи составляли до 1551 г. [13, с. $78-$ $79 ; 16 ; 19$, с. $7 ; 31$, с. $39 ; 32$, с. $206-207]$. По мнению 3.В. Дмитриевой, «борьба государства за монастырское и церковное имущество началась задолго до Стоглавого собора и продолжалась до секуляризации 1764 г.» [19, с. 9]. Многие монастырские описания в XVII в. составляли по инициативе государства, например, известно четыре таких описи КириллоБелозерского монастыря 1601, 1615, 1621, 1635 годов. С.А. Никонов показал, что первая перепись церквей и монастырей Кольского уезда, проведенная светскими властями, состоялась в 1711 г., когда воевода Кольского острога А.В. Матюшкин получил царское распоряжение об этом из Вологды [22, с. 26].
И.А. Булыгин и М.С. Черкасова обратили внимание на указы Петра I 1696 и 1697 гг. об установлении государственного контроля над деревянным, каменным и келейным строительством в архиерейских домах, монастырях и церквях [6, с. 66-68; 32, с. 118-119]. Так, в 1696/97 г. возникла переписная книга церквей Великоустюжской епархии, в которой зафиксированы денежные средства, хлеб, архивы и другие сведения о материальном благосостоянии храмов [33, с. 117-130].

Масштабное описание земель и имущества духовных вотчинников 1701-1705 гг., проведенное в рамках церковной реформы Петpa I, следует рассматривать как этап в осуществлении контроля государства за материальным благосостоянием Церкви [27, с. 122124]. По мнению И.М. Покровского, в это время государство «высвободилось из-под опеки церковной иерархии», а «старая русская жизнь... подверглась всецелой ломке». Историк полагал, что высшая иерархия потеряла государственное значение, а для Петра I важны были отдельные личности [23, с. 2]. И.М. Покровский пришел к выводу, что в результате преобразований «с государственных отправлений снята печать церковности и на многие церковные дела наложена печать гражданственности» [23, с. 3]. На религию и церковь Петр I, по мнению И.М. Покровского, выработал «утилитарный взгляд», они были нужны царю для «внутреннего спокойствия и материального благополучия государства» [23, с. 3].

Защита церковного имущества зафиксирована в следующих постановлениях. Согласно 24 правилу IV Вселенского Халкидонского собора (451 г.) «Единожды освященным по 
изволению епископа монастырям пребывати монастырями навсегда. Принадлежащие им вещи сохраняти и впредь не быти оным мирскими жилищами. Попускающие же сему быти да подлежат наказаниям по правилам» [25, с. 232]. Приведенные выше нормы повторяет 49 правило VI Вселенского Константинопольского собора (680-681 гг.) и конкретизирует наказание: «...дерзающие же от настоящего времени творити сие да подлежат епитимии по правилам» [25, с. 451]. Согласно 13 правилу VII Вселенского Никейского собоpa (787 г.) санкция за лишение монастырей собственности формулировалась следующим образом: «...сущих от священнического чина повелеваем извергати, а монахов или мирян отлучати яко осужденных от Отца, и Сына, и Святаго Духа, и да вчинятся, идеже червь не умирает, и огнь не угасает (Марк. 9:44). Понеже они гласу Господню противятся, глаголющему: Не творите дому Отца моего домом купли (Иоан. 2:16)» [25, с. 691-692]. Эти нормы имелись в Кормчей 1653 г. и наверняка были известны царю и иерархам в начале XVIII века. Если предыдущие цари запрещали приобретать духовенству новые вотчины, то Петр I пошел на нарушение традиции и начал секуляризацию $[1$, с. $350-351 ; 27$, с. 142].

А.А. Завьялов рассмотрел церковные и светские правовые нормы о праве церкви владеть движимым и недвижимым имуществом. Он показал, что по законам Юстиниана для отчуждения церковной и монастырской недвижимости требовалось: 1) «чтобы каждый раз на отчуждение издан был указ императора; 2) чтобы отчуждаемое имущество было возмещено другим; 3) чтобы отчуждаемое имущество употреблено было на общеполезные нужды» [15, с. 19]. По мнению ученого «опыт секуляризации церковных имений не удался в Византии, как не удался он и в России в XVI в., не за отсутствием формального права на такое дело, а потому только, что не было достаточного повода к нему, а у светской власти недоставало силы и ясного понимания вещей» $[15$, с. 20$]$. Таким образом, А.А. Завьялов считает, что если «церковь существует в пределах государства», то последнее имеет право забирать церковное имущество, предоставив иные источники существования для церквей, монастырей и архиерейских кафедр $[15$, с. $21-22]$. По мнению ученого, деятельность Монастырского приказа при Петре I была направлена на упорядочение сбора налогов с церковных вотчин, а не на секуляризацию [15, с. 62]. Однако далее приводятся сведения о том, что из «состава церковных имений вышло» 6407 дворов $[15$, с. 63$]$.

Методы и материалы. И.А. Булыгин впервые рассмотрел комплекс документов, которые возникли в результате осуществления церковной реформы Петра I и отложились прежде всего в ф. 237 (Монастырский приказ) в РГАДА. С точки зрения исследователя «самую важную по значению и самую большую по количеству группу... представляют переписные книги, которые составлялись на владения каждого монастыря и архиерейского дома» $[6$, с. 33]. И.А. Булыгин составил перечень описей 1701-1705 г. [6, с. 311-325]. В него включены документы из РГАДА по истории 213 архиерейских домов, монастырей, пустынь и церквей, из Вологодской епархии упомянуты описания 11 обителей [РГАДА. Ф. 237 (Монастырский приказ). Оп. 1. Ч. І. Ед. хр. 13, 14, 17, 18, 2125, 2734, 3638a, 40; Оп. 1. Ч. III. Ед. хр. 6375]. Однако не все описи монастырей и пустынь, которых к этому времени было в России около 700 [11, с. 535], были учтены в этой работе. М.С. Черкасова показала, что в Вологодской епархии переписи должны были подвергнуться 32 степенных и нестепенных монастыря, а их описи находятся не только в РГАДА, но и в ГАВО [30].

В последние десятилетия ученые исследуют и публикуют описи монастырей начала XVIII века. Н.В. Соколова проанализировала организационные принципы и практику проведения переписных работ в Нижегородском уезде [28]. А.Н. Говорова опубликовала опись Симоно-Воломского монастыря Устюжской епархии 1702 г. [12]. И.Н. Шамина осуществила серию публикаций описей вологодских монастырей начала XVIII в.: вышли в свет известные ранее описи Спасо-Иннокентиева Комельского монастыря 1701 г. [38], Григорьево-Пельшемского Лопотова 1701 г. [34] и не введенные до этого в научный оборот описи Троицкого Павлово-Обнорского монастыря 1701/02 г., [35] Успенской Семигородней пустыни 1702 г. [36], а также коломенских монастырей [37]. В 2011 г. коллективом исследо- 
вателей под руководством М.С. Черкасовой были опубликованы описи начала XVIII в. Спасо-Каменного и Сямженского Евфимиева монастырей [20, с. 137-201, 248-260]. Н.В. Башнин выявил и опубликовал переписные книги Дионисиево-Глушицкого монастыря и его вотчины 1701-1702 гг. [5].

И.А. Булыгину были известны описания владений трех архиерейских домов начала XVIII в.: Крутицкого (Сарский и Подонский), Белгородского и Тамбовского [6, с. 318]. А.Е. Виденеева выявила опись вотчины Ростовского архиерейского дома 1701-1702 гг., которая дошла в виде трех обширных фрагментов [10]. Публикаций описаний вотчин архиерейских домов начала XVIII в. не осуществлено.

В данной статье был применен метод текстологического анализа исследуемых источников. Кроме того, было проведено сравнение сведений из источников разного происхождения.

Анализ. В РГАДА среди материалов Монастырского приказа (ф. 237) хранятся переписные книги вотчин Вологодского архиерейского дома Св. Софии в Московском, Вологодском, Яренском, Усольском и Галицком уездах, а также приписных Антоньевой, Кохтожской пустынь и Николо-Мокрого монастыря 1701-1702 гг. [21]. Этот источник впервые в научный оборот ввел И.М. Покровский, который дает следующую ссылку: «Арх. Мин. Юст. по Мон. Прик. кн. № 53» [23, с. 7], она тождественна современному шифру «РГАДА. Ф. 237. ОП. 1. Ед. хр. 53». Он отметил, что для переписи вотчин посылали «добрых» людей из царедворцев и, например, в Вологодской епархии производили перепись стольники Василий Кошелев, Андрей Вешняков, Иван Нелидов и Василий БогдановичПлохово [23, с. 7]. С этим утверждением нельзя полностью согласиться, поскольку они / стольники проводили описание не в Вологодской епархии, а в Московском, Вологодском, Яренском, Усольском и Галицком уездах. Разные переписчики описывали вотчины Вологодского архиерейского дома в пяти регионах страны, что говорит о поуездном принципе работ. И.М. Покровский переписные книги вотчин Вологодской кафедры 1701-1702 гг. в своем труде далее не привлекал.

В 1976 г. вышла монография Е.Н. Швейковской (Баклановой), построенная на докумен- тальных материалах Вологодского архиерейского дома и Спасо-Прилуцкого монастыря конца XVII - начала XVIII века. Она отметила, что в 1702-1703 гг. стольник В.И. Кошелев провел перепись архиепископских владений, основываясь на наказе, присланном в Вологду [2, c. 52]. Основное внимание Е.Н. Швейковская уделила переписи хозяйства Вологодской кафедры в Вологодском уезде, которая хранится в НИОР РГБ (самоназвание - «книги ведомостем» или «ведомости с перечнями по статьям») [9], а также привлекла опись вотчины Вологодского архиерейского дома Св. Софии из РГАДА (самоназвание - «переписные книги») [2, с. 85].

Раскроем, в чем заключается различие этих источников. При составлении переписных книг вотчин Вологодского архиерейского дома 1701-1702 гг. внимание переписчиков было сконцентрировано на следующих объектах: населенные пункты, дворы крестьян и бобылей, мужское население этих дворов всех возрастов, церкви, их внешний вид и убранство. Программа переписи была зафиксирована в преамбуле [21, л. 74].

В переписи хозяйства (ведомостях) Вологодского архиерейского дома 1702-1703 гг. при описании сел приведены сведения о размерах домовой запашки, величине денежных и натуральных сборов с крестьян, о количестве запасов в амбарах (хлеб, рыба, икра, масло), составлен перечень крестьян, которые взяли в долг хлеб с указанием поселения, имени должника и объема зерна. Переписчик зафиксировал денежный оброк, собираемый в архиерейскую казну с крестьянских мельниц и пустошей. По каждой из деревень в вотчине отмечены изменения в численности дворов от 1678 г. к 1702 г., размеры земельных угодий за каждым населенным пунктом обозначены по данным писцового описания 1628 1630 гг., а также учтено вытное обложение к 1702-1703 годам. Е.Н. Швейковская подчеркнула, что этот источник позволил выяснить «размер надела и тяжесть обложения каждого крестьянского двора» и «порайонное распространение в данной вотчине видов феодальной ренты и удельный вес (по числу отбывавших дворов) каждого из ее видов» [2, с. 53].

Для понимания обширной программы описания хозяйственных объектов в вотчинах 
Вологодской кафедры приведем фрагмент преамбулы документа 1702-1703 гг.: «...домовым вотчинам, селам и деревням, что в них порознь крестьянских и бобыльских дворов по переписным книгам 186-го году и что в которой деревне прибыло ... по нынешней переписке [...] в селах, и в деревнех, и в пустошах по писцовым [...] и по дачам что четвертные пашни $[. .$.$] и лесу, и всяких угодей, и что в ко-$ торых [...] вытного тягла вытей и осмаков [...] и сколко в котором селе на архиерейской [...] пашут земли десятин и в прошлом [...] ржы и ярового $[\ldots]$ сотниц $[\ldots]$ из которые в умолоте [...] было ржы [...] ныне в житницах [...] хлеба по розписи и в тяглах [...] ржи и всяких столовых запасов, и что с которой вотчины по окладу крестьян денежных доходов, также столовых запасов, и конюшенных, и дворцовых [припа] сов во взятых бывает, и по сколку в архиерейской дом с мелниц оброчных помолных денег, и по сколку четвертей на которой мелнице $[. .$.$] архиерейской росход и бес-$ помолно мелют, также что бывает со всяких оброчных статей в приходе денежных доходов, и по сколку [...] масла коровья, грибов, груздей $[\ldots]$ столовых запасов, и в архи[ерейский...] почему бывает в росходе в церквах $[\ldots]$ на свечи, на воск, на вино [...] и домовых всяких чинов людем [...] денежного и хлебного жалованья [...] сажен в год в росходе [...] и что $[\ldots]$ к сенокосу $[\ldots]$ и полей в архиерейской дом сена коситца, и кто те сена косит, и что в нынешнем году накошено сена копен...» [9, л. 1-2].

Сравнение преамбул показывает, что перед переписчиками стояли разные задачи. При составлении переписных книг основной целью была подворная перепись населения архиерейских вотчин (с перечислением людей мужского пола всех возрастов), а значит, выяснение количества налогоплательщиков. Переписные книги церковных вотчин 1701-1702 гг. можно рассматривать как сокращенный вариант общероссийского кадастра. При составлении хозяйственной переписи (ведомостей) основной целью было выяснение источников и объемов доходов и расходов архиерейской кафедры. Проведем сравнение текстов двух источников начала XVIII в. на примере описания села Ивановского в Ракульской волости Вологодского уезда (табл. 1).
Приведенное сопоставление текстов показывает, что переписные книги вотчин Вологодского архиерейского дома 1701-1702 гг. были первичными по отношению к переписи хозяйства (ведомостям) Вологодского архиерейского дома 1702-1703 годов. Очевидно, что сначала была проведена подворная перепись населения, а потом ее результаты сопоставили с предыдущим описанием 1678 г. по каждому населенному пункту. Приведенные выше цитаты из двух документов также показывают, что описание вотчины было сделано в традициях писцового делопроизводства XVI-XVII вв., а описание хозяйства (ведомости) представляет собой уже новый тип документа, в котором приводятся ответы на ряд поставленных вопросов, для этого привлекаются материалы семидесятилетней давности - писцовые книги 1627-1630 годов. Подобная ситуация, когда в одной книге переписывали материальные ценности и хозяйство, а в другой - вотчину, зафиксирована при описании монастырей и их владений [5;34].

Для того чтобы проследить изменения в формуляре описания и влияние кадастровых документов на переписные книги архиерейских вотчин 1701-1702 гг., сравним, как писцы зафиксировали село Павловское в Лежском Волоке Вологодского уезда в писцовых и переписных книгах 1627-1630, 1646, 1678, 1702 гг. (табл. 2). Из таблицы 2 видно, что за 70 лет изменился формуляр описания вотчины, с 1640-х гг. не учитывались пашня, сенокос, лес. В 1678 и 1702 гг. учтены дворы и все мужское население, а также отмечены «сшедшие» люди. Формуляр переписных книг 1678 и 1702 гг. идентичен, при этом подворное сравнение показывает, что при составлении переписи 1702 г. переписная книга 1678 г. не использовалась, поскольку порядок перечисления дворов разный (табл. 2, столбцы 3 и 4). Заметим, что село Павловское в течение XVII в. превратилось из церковно-административного населенного пункта в деревню, где проживали крестьяне.

Описание погоста с двумя церквями в 1678 и 1702 гг. было отделено от деревни, которая выросла неподалеку от храмов, ниже сравним два описания храмовых комплексов (табл. 3).

Проведенное сравнение текстов описания Преображенского прихода на р. Сеянге 
показало, что в 1678 г. писцы зафиксировали здания церквей и дворы причта с указанием жителей мужского пола, а в 1702 г. были описаны не только здания, но и внутренне убранство храмов (иконы, утварь, книги), а также дворы причта. Кроме того, в документе начала XVIII в. также есть сведения о храмовой собственности и церковном старосте, чего не было отмечено раньше. Замечу, что так подробно, как в 1702 г., описывали храмы во время дозоров 1610-х годов. Документов по Лежскому Волоку этого времени не известно, но выявлено описание Леонтьевского погоста в вотчине Глушицкого монастыря в дозорной книге 1615/16 г. [4, с. 1035-1036].

Для выяснения преемственности проживания сравним состав жителей деревни Павловское в Лежском Волоке Вологодского уезда по двум хронологическим срезам (табл. 4).

Из приведенного перечня дворов в деревне Павловское видно, что не менее чем в 5 случаях сохранялась семейная преемственность проживания в этом населенном пункте, но за 24 года появилось шесть дворов, очевидно, населенных вновь прибывшими людьми. Этот локальный пример показывает движение населения в вотчинах Вологодского архиерейского дома и подтверждает отмеченное в историографии явление внутривотчинной миграции и ухода за пределы вотчин зависимого населения до и после Соборного уложения 1649 г. [3; 14].

Кроме названных выше источников начало церковной реформы Петра I повлекло за собой появление описи казны Вологодского Софийского дома. Стольник В.И. Кошелев произвел перепись материальных ценностей и документов 3 июня 1701 года. Для того чтобы была понятна программа описания, приведем фрагмент преамбулы из переписной книги: «<...> стольник Василей Иванович Кошелев, приехав на Вологду в дом преосвященного Гавриила архиепископа Вологодского и Белозерского, а в нем ризницу, а в архиерейских казенных полатах приходные и росходные книги з 203-го году, также приписным монастырем и вотчинам окладные книги же, и золотые, и ефимки, и денги, и золотую, и серебряную, и оловяную, и медную посуду, и всякую казну жалованные грамоты, вкладные, и иные всякие вотчинные кре- пости, и зделочные писма запечатал, и из печати по описным книгам, каковы подали за руками в ризнице ризничей протодьякон Стефан Автамонов, а в казне казначей монах Никандр, пересматривал, а в церквах Божиих святые иконы окладные и неокладные, и церковные сосуды, и книги, и всякую церковную утварь переписывал <..> А серебряные церковные сосуды, а в казенных полатах серебряную же, и медную, и оловяную, и всякую посуду, и медь, и олово весил на вологодские таможенные и домовые весы» [17, л. 1]. Из этого текста видно, что переписчиков интересовали грамоты, обосновывающие право собственности, приходо-расходные книги и материальные ценности, которые хранились в архиерейском доме.

Результаты. Создание трех переписей (вотчины, хозяйства, казны) дало государству документы, на основании которых можно было составить полное представление о хозяйстве и имуществе Вологодского дома Св. Софии, поэтому согласимся с И.А. Булыгиным, который считал, что «в 1701-1705 гг. Петром I была проведена не частичная и временная, а фактически полная секуляризация церковных владений» [6, с. 20].

После составления описаний финансовую и хозяйственную деятельность Вологодской кафедры стали контролировать из Монастырского приказа во главе с И.А. Мусиным-Пушкиным [26, с. 236]. В результате этого приходо-расходные книги и другие хозяйственные документы 1702-1703 гг. пересылали в Москву, где они отложились в фонде этого учреждения в РГАДА [29, с. 199-416]. В Научноисторическом архиве Санкт-Петербургского института истории РАН в коллекции Н.П. Лихачева также были выявлены три документа начала XVIII в. из архива Вологодского дома Св. Софии: 1) ведомости, составленные по памяти из Казенного приказа, о посевах и сборе хлеба в вотчинах Вологодского архиерейского дома и монастырей 1705 г. [8]; 2) ведомости о монастырях 1723 г. [7]; 3) окладная книга церквей Вологодской епархии 1724 г. (в этом источнике каждый храм идет под своим порядковым номером, но поскольку начало документа утрачено, то на л. 1 зафиксирована 46-я церковь, а последняя под номером 339 на л. 48 об.) [17]. 
Судя по ведомостям 1705 г., сбор хлеба контролировался «из Вологды из Казенного приказа», а память о составлении ведомостей в монастырях и архиерейской вотчине была прислана за скрепой Семена Герасимовича Брянчанинова. В ведомости 1705 г. занесены сведения о посеве, умолоте хлеба (рожь, ячмень, овес), отмечено наличие семян. Для контроля были предоставлены данные о хлебе в селах из архиерейской вотчины (в Засодимской волости - Стефановское, Григорьевское, Цыбоево; подгородных - Ананьино, Ивановское, Белое, Реброво), в монастырях (Павлове, Спасо-Каменном, Подольном, Арсеньеве Сахарусове, Успенском Песочном, Евфимьеве, Катромском, Сямском Рождества Богородицы, Глушицком), а также в пустынях (Арсеньевой на Маслене, Цывецкой, Николая Чудотворца Мокрой, Александро-Куштской, Репной, Семигородней, Спасской на Лому, Вондожской).

В литературе высказано мнение о постепенном возвращении монастырям вотчин (со ссылкой на законы 1718 и 1720 гг.) [26, с. 236]. Однако этот процесс в Вологодской епархии начался раньше. В ведомости о монастырях 1723 г. представлены данные с того момента, как к обителям вернули вотчины, а это ока- зывается для Корнильева - 1713 г., Печенгского - 1710 г., Подольного - 1710 г., Инокентиева - 1713 г., Николаевского Озерского 1713 г., Спасо-Нуромского - 1713 г., Дионисиево-Глушицкого - 1713 год.

Вологодскому архиерейскому дому Св. Софии вотчины вернули в 1713 году. Об этом становится известно из указа к архиепископу Вологодскому и Белозерскому Иосифу от 8 июня 1713 года. Согласно этому документу «ему, архиерею, домовыми своими вотчинами $<$.. > владеть $<$.. $>$ А коммисарам $<\ldots>$ не быть. А всякие тех вотчин с крестьян подати, также и с церквей данные, и всякие окладные и неокладные доходы собирать в его архиерейской дом по окладу сполна...» [24, № 2686]. В указе от 17 сентября 1716 г. также говорится о том, что с 1713 г. домовой вотчине на Лежском Волоке «быть в доме его архиерейском по-прежнему» [24, № 3038].

Таким образом, в результате церковной реформы Петра I возникло значительное количество документации, среди которой описания 1701-1703 гг. занимают особое место. Эти книги, по мнению Е.Н. Швейковской, подводят «итог состоянию вотчины в конце XVII в.» и служат «отправной точкой для XVIII в.» [2, с. 85]. 


\section{ПРИЛОЖЕНИЕ}

\section{Таблица 1. Описание вотчин Вологодского архиерейского дома в документах 1701-} 1703 гг.

Table 1. Description of the patrimonies of the Vologda Bishop's house in the documents of 1701-1703

\begin{tabular}{|c|c|}
\hline $\begin{array}{c}\text { Переписные книги вотчины } \\
\text { Вологодского архиерейского дома Св. Софии 1701- } \\
1702 \text { гг. (РГАДА. Ф. 237. Оп. 1. Ед. хр. 53. Л. 19-23 об.) }\end{array}$ & $\begin{array}{c}\text { Переписные книги (ведомости) хозяйства } \\
\text { Вологодского архи ерейского дома Св. Софии 1702- } \\
1703 \text { гг. (НИОР РГБ. Ф. 354. Ед. хр. } 177 . \\
\text { Л. 46-48 об., 103-104 об., 105) }\end{array}$ \\
\hline $\begin{array}{l}\text { За ним же, преосвященным архиепископом, вотчина } \\
\text { в Вологодском же уезде в Ракулской волости на реке } \\
\text { на Вологде село Ивановское з деревнями }\end{array}$ & $\begin{array}{l}\text { Преосвященного Гавриила архиепископа <..> в вот- } \\
\text { чине в Вологодском уезде в Ракулской волости село } \\
\text { Ивановское }\end{array}$ \\
\hline- & 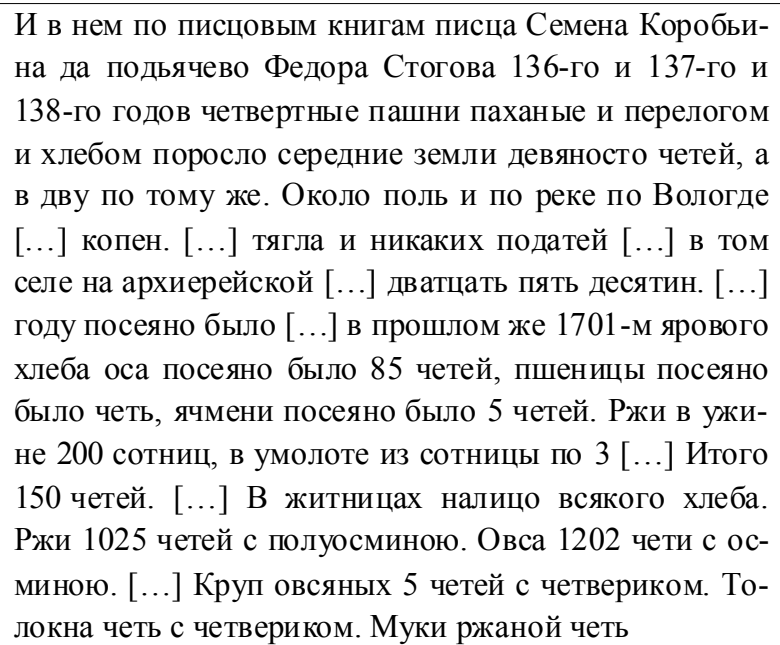 \\
\hline $\begin{array}{l}\text { А в нем церковь древяная холодная во имя Иоанна } \\
\text { Богослова, верх шатровой. В церкви Божия милосер- } \\
\text { дия святых образов. Царские двери, и сень, и столбцы } \\
\text { писаны на золоте. По правую сторону царских дверей } \\
\text { образ Живоначалные Троицы, писан на золоте. Образ } \\
\text { Иоанна Богослова. Венец серебряной резной. Образ } \\
<\ldots .>\text {. Среди церкви паликадило медное маленкое. } \\
\text { Пред Святителевым образом паликадило маленкое } \\
\text { медное же. В олтари <..>. У царских дверей завеса } \\
\text { крашенинная. Другая церковь теплая во имя Николая } \\
\text { Чюдотворца древяная же <..>. В трапезе. Образ Ни- } \\
\text { колая Чюдотворца в житии, писан на золоте <..>. Три } \\
\text { лампады неболших железа белого. Книг печатных в } \\
\text { десть. Апостол. Псалтирь со воследованием <...>. Ко- } \\
\text { локолня древяная, на ней четыре колокола неболших, } \\
\text { а по скаске церковного старосты Анички Никитина, } \\
\text { весу в них десять пуд. У той церкви священник Ио- } \\
\text { сиф Яковлев, родом Шуйского городка храму Вос- } \\
\text { кресения Христова, священников сын, у него детей } \\
<. .>\end{array}$ & $\begin{array}{l}\text { В то же село дают из домовой казны в церковь ладану } \\
\text { по } 2 \text { фунта. Свеч восковых по } 3 \text { фунта. Церковного } \\
\text { вина по четверте ведра }\end{array}$ \\
\hline $\begin{array}{l}\text { В том же селе двор архиепископль построен на при- } \\
\text { езд. На нем хоромного строения <..> }\end{array}$ & - \\
\hline
\end{tabular}


Продолжение таблищь 1

Continuation of Table 1

\begin{tabular}{|c|c|}
\hline $\begin{array}{c}\text { Переписные книги вотчины } \\
\text { Вологодского архиерейского дома Св. Софии 1701- } \\
1702 \text { гг. (РГАДА. Ф. 237. Оп. 1. Ед. хр. 53. Л. 19-23 об.) }\end{array}$ & $\begin{array}{c}\text { Переписные книги (ведомости) хозяйства } \\
\text { Вологодского архиерейского дома Св. Софии 1702- } \\
1703 \text { гг. (НИОР РГБ. Ф. 354. Ед. хр. } 177 . \\
\text { Л. } 46-48 \text { об., 103-104 об., 105) }\end{array}$ \\
\hline- & $\begin{array}{l}\text { В том же селе в сушилах рыбы, икры, вязиги, масла } \\
\text { коровья и семяного меду и иных столовых запасов } \\
\text { нет. Того же села с принадлежащих деревень с кре- } \\
\text { стьян денежных доходов и иных столовых запасов во } \\
\text { взятье никогда в то село не бывает. В том же селе ни- } \\
\text { каких торжков, ярманок и оброчных мелниц нет. Про } \\
\text { селской росход хлеба мелют того села крестьяня в } \\
\text { домех своих по розвытке меж собою безпомолно. } \\
\text { Ржы по } 20 \text { четей. На квас солоду ржаного и овсяного } \\
\text { по } 10 \text { четей. [...] овсяных и толокна по } 6 \text { четей. [...] } \\
\text { селе рыбных ловель нет. [...] оброчных статей в при- } \\
\text { ходе [...при]ходов в то село не бывает }\end{array}$ \\
\hline $\begin{array}{l}\text { Двор конюшенной, на нем хоромного строения: у во- } \\
\text { рот горница на жилом подклете, против горница же } \\
\text { холодная, меж ими сени. На дворе же конюшном в } \\
\text { нем четыре стойла, огорожен забором, кругом сараи. } \\
\text { А в нем живет поселской старец Афонасий, да цело- } \\
\text { валник Васка Васильев, да повар Куска Семенов, ро- } \\
\text { дом того же села деревни Кишкина, крестьянской } \\
\text { сын, на год ему дают из домовой казны на платье по } \\
\text { рублю. В конюшне на стойле жеребец ворон, грива } \\
\text { направо <... Р. На дворе скота <..>. Живет на том дво- } \\
\text { ре коровник Мануилка Никитин. На дворе скота <... } \\
\text { Да в том же селе Ивановском два двора, живут в них } \\
\text { конюхи: во дворе Васка Костянтинов, во дворе Васка } \\
\text { же Иванов. А что поселскому старцу, и целовалнику, } \\
\text { и конюхом, и коровнику денежного и хлебного жало- } \\
\text { ванья из домовой казны дают, и где кто родился, и } \\
\text { что у конюхов и у коровника детей и в каковы лета, и } \\
\text { то писано в переписных домовых книгах домовыми } \\
\text { архиерейскими людми имянно }\end{array}$ & $\begin{array}{l}\text { Того же села поселскому монаху преж сего было на } \\
\text { год денежного жалованья } 4 \text { рубля. Целовальнику } \\
3 \text { рубля. Двум человеком конюхам } 5 \text { рублев } 16 \text { алтын } \\
4 \text { денги. Хлеба ржы } 7 \text { четей, овса то же. Коровнику } \\
3 \text { рубля. Хлеба ржы } 4 \text { чети, овса то же. Работнику } \\
1 \text { рубль }\end{array}$ \\
\hline- & $\begin{array}{l}\text { Про селской росход в росходе дров }[\ldots] \text { сажень те } \\
\text { дрова пороз[нь...] привозят в то село те же вышепи- } \\
\text { санные крестьяна. В то же село к пашне к сеннокосу } \\
\text { подводы и работники бывают с тех же вышеписан- } \\
\text { ных крестьян. Сена они косят. Для прекормления до- } \\
\text { мового скота в то же село. По берегу реки Вологды } \\
\text { поставлено сена на тритцати на трех десятинах с по- } \\
\text { лудесятиной } 16 \text { стогов, а в тех стогах } 335 \text { копен [...] } \\
\text { возами } 67 . \text { В дву полях поставлено сена на тритцати } \\
{[\ldots] \text { десятине с полудесятиной [...ст]огов [...] тех }} \\
\text { стогах } 315 \text { копен с [...]ами } 63 . \text { К тому же селу для } \\
\text { скотского выпуску пустоши <...>. Сена } 30 \text { копен. Ле- } \\
\text { су пашенного } 2 \text { десятины, а непашенного } 3 \text { десятины }\end{array}$ \\
\hline
\end{tabular}




\section{ИСТОРИЯ УПРАВЛЕНИЯ И ДЕЛОПРОИЗВОДСТВА В РОССИИ}

\section{Окончание таблицьы 1}

End of Table 1

\begin{tabular}{|c|c|}
\hline $\begin{array}{c}\text { Переписные книги вотчины } \\
\text { Вологодского архиерейского дома Св. Софии 1701- } \\
1702 \text { гг. (РГАДА. Ф. 237. Оп. 1. Ед. хр. 53. Л. 19-23 об.) }\end{array}$ & $\begin{array}{c}\text { Переписные книги (ведомости) хозяйства } \\
\text { Вологодского архиерейского дома Св. Софии 1702- } \\
1703 \text { гг. (НИОР РГБ. Ф. 354. Ед. хр. } 177 . \\
\text { Л. 46-48 об., 103-104 об., 105) }\end{array}$ \\
\hline $\begin{array}{l}\text { В том же селе Ивановском четыре анбара хлебных, а } \\
\text { в них по скаске и по смете поселского старца Афона- } \\
\text { сия и целовалника Васки Васильева хлеба ржи пять- } \\
\text { сот чети, овса шестьсот чети, пшеницы чети с три, } \\
\text { ячмени чети с пяти. А тот-де вышеписанной хлеб } \\
\text { держат они про домовой росход. А болши того в том } \\
\text { селе Ивановском никакова хлеба нет }\end{array}$ & - \\
\hline- & $\begin{array}{l}\text { К тому же селу крестьянских и бобыльских дворов } \\
\text { порознь по переписным книгам } 186 \text {-го году [...] по- } \\
\text { сле переписных книг } 186 \text {-го году по ныне[шней] пе- } \\
\text { реписке столника Василья Кошелева }[\ldots] \text { и то писано } \\
\text { ниже сего }\end{array}$ \\
\hline $\begin{array}{l}\text { Деревня Ивашково, а в ней крестьян: во дворе Ларка } \\
\text { Гаврилов, у него детей, Федка десяти лет, Никешка } \\
\text { трех лет; во дворе Егорко Яковлев, у него брат Мои- } \\
\text { сейко дватцати пяти лет, у Егорка сын Ивашко дват- } \\
\text { цати лет; во дворе Ивашко Савельев, у него детей, } \\
\text { Алешка пятнатцати лет, Мишка десяти лет; во дворе } \\
\text { Федка Григорьев, у него детей, Ивашка пятнатцати } \\
\text { лет, Васка шти лет, Сенка дву лет; во дворе Митка } \\
\text { Иванов; во дворе Лучка Иванов, у него сын Мишка, у } \\
\text { Мишки сын Андрюшка пятнатцати лет; во дворе } \\
\text { Стенка Гаврилов, у него детей, Гераска, Андрюшка } \\
\text { даватцати лет, у Гераски сын Алешка полутрети года; } \\
\text { во дворе Оска Никитин з братом Ларкою, у Оски сын } \\
\text { Левка пятнатцати лет; во дворе Мишка Гаврилов, у } \\
\text { него детей, Ларка дватцати четырех лет, Титко две- } \\
\text { натцати лет, Ганка трех лет }\end{array}$ & $\begin{array}{l}\text { Деревня, что было селцо Ивашково на речке на Дол- } \\
\text { гуше, а в ней по переписным книгам } 186 \text {-го году } \\
\text { шесть дворов. А по нынешней переписке девять дво- } \\
\text { ров. Прибыло три двора. По писцовым книгам и по } \\
\text { дачам четвертные пашни паханые середние земли } \\
\text { семь четей с осминой да перелогом пятнатцать четей, } \\
\text { да лесом поросло дватцать пять четей в поле, а в дву } \\
\text { по тому же. Сена сорок копен. Вытного окладу пол- } \\
\text { торы выти }\end{array}$ \\
\hline
\end{tabular}


Таблица 2. Описание села (деревни) Павловского в Лежском Волоке Вологодского уезда в писцовых и переписных книгах XVII - начала XVIII в.

Table 2. Description of Pavlovskoe village in Lezhsky Volok of Vologda region in census books of the $17^{\text {th }}-$ early $18^{\text {th }}$ century

\begin{tabular}{|c|c|c|c|c|}
\hline $\begin{array}{l}1620 \text { г. (по сотной } \\
\text { грамоте } 1624 \text { г.) }\end{array}$ & $1627-1630$ гг. & 1646 г. & 1678 г. & 1702 г. \\
\hline $\begin{array}{l}\text { Вологодцкого архи- } \\
\text { епископа в вотчине } \\
\text { Лиской Волок, а в } \\
\text { нем село Павлов- } \\
\text { ское на речке на Се- } \\
\text { енге. А в нем во } \\
\text { дворе архиепи- } \\
\text { скопль дворник да } \\
\text { мелник Сенка Мар- } \\
\text { ков. Пашни паханые } \\
\text { наездом <... С. Сена } \\
\text { по реке <..>. Да у } \\
\text { того же села на реч- } \\
\text { ке на Сеенге мелни- } \\
\text { ца немецкая, а в ней } \\
\text { одни жерновы, ме- } \\
\text { лет на архиеписко- } \\
\text { па. Да того же села } \\
\text { сенные покосы <...>. } \\
\text { Лесу болшого у того } \\
\text { села на десять верст }\end{array}$ & $\begin{array}{l}\text { В Лежском Волоку } \\
\text { вотчина Вологоцко- } \\
\text { го архиепископа се- } \\
\text { ло Павловское на } \\
\text { речке на Сеянге, а в } \\
\text { нем двор архиепи- } \\
\text { скопль. Пашни па- } \\
\text { ханые наездом <..>. } \\
\text { Сена по реке <..>. } \\
\text { Да у того же села на } \\
\text { реке на Сеенге мел- } \\
\text { ница немецкая, а в } \\
\text { ней одне жорновы. } \\
\text { Да у того же села } \\
\text { сенные покосы <..>. } \\
\text { Леса болшаго у того } \\
\text { села на десять верст }\end{array}$ & - & - & - \\
\hline $\begin{array}{l}\text { Погост на речке на } \\
\text { Сеенге, а на погосте } \\
\text { церковь боголепное } \\
\text { Преображене, дру- } \\
\text { гая церковь теплая } \\
\text { Никола Чюдотворец } \\
\text { <..>. У церкви во } \\
\text { дворе поп Иван } \\
\text { <..>. Пашни цер- } \\
\text { ковные середние } \\
\text { земли дватцать че- } \\
\text { тей в поле, а в дву } \\
\text { по тому же. Сена } \\
\text { пятнатцать копен }\end{array}$ & $\begin{array}{l}\text { Погост на реке на } \\
\text { Сеенге, а на погосте } \\
\text { церковь боголепное } \\
\text { Преображение, дру- } \\
\text { гая церковь Николы } \\
\text { Чюдотворца, обе } \\
\text { древяны клетцкие } \\
<. .>\text { У церкви слу- } \\
\text { жат поп Иван <...>. } \\
\text { Пашни церковные } \\
\text { середние земли } \\
\text { дватцать чети в по- } \\
\text { ле, а в дву по тому } \\
\text { же. Сена пятнатцать } \\
\text { копен }\end{array}$ & $\begin{array}{l}\text { Вотчина преосвя- } \\
\text { щеннаго архиепи- } \\
\text { скопа Маркела Во- } \\
\text { логодцкого и Вели- } \\
\text { копермского село } \\
\text { Павловское на речке } \\
\text { на Сеянге, а в нем } \\
\text { погост Спаской, а на } \\
\text { погосте церковь бо- } \\
\text { голепное Преобра- } \\
\text { жение Господа на- } \\
\text { шего Исуса Христа } \\
\text { древяна вверх клин- } \\
\text { чатая, другая цер- } \\
\text { ковь Николы Чюдо- } \\
\text { творца древяна } \\
\text { клецки. На погосте } \\
\text { же: во дворе поп } \\
\text { Ефрем Иванов с сы- } \\
\text { ном с Любимком } \\
<. .>\quad\end{array}$ & - & - \\
\hline
\end{tabular}




\section{ИСТОРИЯ УПРАВЛЕНИЯ И ДЕЛОПРОИЗВОДСТВА В РОССИИ}

Окончание таблицы 2

End of Table 2

\begin{tabular}{|c|c|c|c|c|}
\hline $\begin{array}{c}1620 \text { г. (по сотной } \\
\text { грамоте } 1624 \text { г.) }\end{array}$ & $1627-1630$ гг. & 1646 г. & 1678 г. & 1702 г. \\
\hline- & - & - & $\begin{array}{l}\text { Деревня, что была } \\
\text { селцо Павловское на } \\
\text { речке на Сеенг, а в } \\
\text { ней крестьян: во } \\
\text { дворе Кондрашка } \\
\text { Гурьев } 3 \text { зятем с } \\
\text { Ывашком Потапо- } \\
\text { вым, у Ивашка брат } \\
\text { Абрашка, у Конд- } \\
\text { рашки пасынки } \\
\text { Федка пятнатцати } \\
\text { лет, Ивашко трех } \\
\text { лет Ивановы дети, у } \\
\text { Абрашки } \quad \text { сын } \\
\text { Алешка трех лет, у } \\
\text { Ивашка Потапова } \\
\text { пасынок Тимошка } \\
\text { Иванов дватцати лет } \\
<. .>\end{array}$ & $\begin{array}{l}\text { Деревня, что было } \\
\text { селцо Павловское, } \\
\text { на речке на Сеянге, } \\
\text { а в ней крестьян: во } \\
\text { дворе Борис Ильин, } \\
\text { у него дети, Дмит- } \\
\text { рей дватцати лет, } \\
\text { Сергей девяти лет; } \\
\text { во дворе Михайло } \\
\text { Яковлев, у него сын } \\
\text { Василей девяти лет; } \\
\text { во дворе Сергей } \\
\text { Карпов, у него брат } \\
\text { Антипа дватцати } \\
\text { лет, у Сергея детей, } \\
\text { Яков двенатцати } \\
\text { лет, Василей десяти } \\
\text { лет, Андрей четырех } \\
\text { лет<..> }\end{array}$ \\
\hline
\end{tabular}

Примечание. Источники: РГАДА. Ф. 281. Ед. хр. 2694. Л. 1; Там же. Ф. 1209. Оп. 1. Ед. хр. 14727. Л. 45-47; Там же. Ед. хр. 14732. Л. 890 об.-892 об.; Там же. Ед. хр. 14733. Л. 116 об.-117; Там же. Ф. 237. Оп. 1. Ч. 1. Ед. хр. 53. Л. 129 об. -130.

Note. Sources: Russian State Archive of Ancient Acts (RGADA), f. 281, dep. item 2694, 1. 1; Ibid. f. 1209, inv. 1, dep. item 14727, 1. 45-47; Ibid. dep. item 14732, 1. 890 r.-892 r.; Ibid. dep. item 14733, 1. 116 r.-117; Ibid. f. 237, inv. 1, part 1, dep. item 53, 1. 129 r. -130 . 
Таблица 3. Описание погоста в вотчине Вологодского архиерейского дома в 1678 и 1701-1702 гг.

Table 3. Description of the churchyard in the patrimony of the Vologda Bishop's house in 1678 and 1701-1702

\begin{tabular}{|c|c|}
\hline $\begin{array}{c}\text { Переписные книги Вологодского } \\
\text { уезда } 1678 \text { г. (РГАДА. Ф. } 1209 . \\
\text { Ед. хр. } 14733 . \text { Л. } 117 \text { об.-118) } \\
\end{array}$ & $\begin{array}{c}\text { Переписные книги вотчины Вологодского архиерейского дома Св. Софии } \\
\text { 1701-1702 гг. (РГАДА. Ф. 237. Оп. 1. Ед. хр. 53. Л. 78-82 об.) }\end{array}$ \\
\hline $\begin{array}{l}\text { Погост на реке на Сеянге, а на по- } \\
\text { госте церковь боголепного Преоб- } \\
\text { ражения Господня древяная клетц- } \\
\text { кая, да церковь Николая Чюдотвор- } \\
\text { ца теплая }\end{array}$ & $\begin{array}{l}\text { В вотчине преосвященного архиепископа на Лежском же Волоку на } \\
\text { речке Сеянге церковь холодная во имя благолепнаго Преображения } \\
\text { Господня клинчатая. А в ней Божия милосердия святых образов. Двери } \\
\text { царские, сень, и столбцы, и корона резные золочены. По правую сторо- } \\
\text { ну царских дверей месных образов. Образ Преображения Господня } \\
<\text { _..>. Пред царскими дверми паликадило медное о двенатцати ручках, у } \\
\text { паликадила внизу астрахакамилово яйцо, обложено медью, у яйца кисть } \\
\text { разных шелков. В олтари <... Р. Ризы отлас червчатой <... У. У царских } \\
\text { дверей завеса крашенинная, пелена выбойчатая, на ней крест краше- } \\
\text { нинной. Завеса выбойчатая, ветха. Книг печатных в десть. Евангелие } \\
\text { толковое. Апостол. Псалтырь со воследованием <..>. Другая церковь } \\
\text { теплая во имя Николая Чюдотворца. А в ней Божия милосердия святых } \\
\text { образов <..>. На монастыре же колоколня рублена в брус. На ней четы- } \\
\text { ре колокола, весу в тех колоколах, по скаске той церкви попа Василия, } \\
\text { тритцать два пуда дватцать пять фунтов. За монастырем у тех церквей } \\
\text { святые врата рубленые, ограда бревенная, невысокая }\end{array}$ \\
\hline $\begin{array}{l}\text { Да на погосте же: во дворе поп По- } \\
\text { лиект Ефремов, у него детей Федка } \\
\text { пяти лет, Васка четырех лет, да у } \\
\text { него же племянники Ивашка Анд- } \\
\text { реев десяти лет, Наумка Никитин } \\
\text { двенатцати лет }<. . .>\end{array}$ & $\begin{array}{l}\text { У тех же церквей: во дворе поп Василей, у него брат диакон Иван По- } \\
\text { лиектовы, родом они того же прихода, поповы дети, у них же племян- } \\
\text { ник Алексей Федоров осми лет; во дворе поп Иван Полиектов, у него } \\
\text { дети, Василей полугоду, родом тое же церкви попов сын; во дворе поп } \\
\text { Иван Андреев, у него сын Василей, году, родом он тое же церкви попов } \\
\text { сын <..> }\end{array}$ \\
\hline- & $\begin{array}{l}\text { По скаске их, попа Ивана с причетники, у тех церквей сколко пашни } \\
\text { церковные земли и сенных покосов, того они сказать не упомнят <...> }\end{array}$ \\
\hline- & $\begin{array}{l}\text { Церковной староста домовой же вотчины крестьянин деревни Бродина } \\
\text { Лука Дорофеев, написан он, староста, в переписных книгах в той же } \\
\text { деревне Бродине. По скаске ево, старосты Луки Дорофеева, в зборе у } \\
\text { него денег и хлеба ничего нет }\end{array}$ \\
\hline
\end{tabular}


Таблица 4. Состав дворов в деревне Павловское с указанием преемственности проживания по переписным книгам 1678 и 1702 гг.

Table 4. Structure of courtyards in Pavlovskoe village with indication of the continuity of residence according to census books of 1678 and 1702

\begin{tabular}{|c|c|c|}
\hline № п/п & 1678 г. & 1702 г. \\
\hline 1 & $\begin{array}{l}\text { Во дворе Кондрашка Гурьев з зятем с Ывашком } \\
\text { Потаповым *, у Ивашка брат Абрашка, у Конд- } \\
\text { рашки пасынки Федка пятнатцати лет, Ивашко } \\
\text { трех лет Ивановы дети, у Абрашки сын Алешка } \\
\text { трех лет, у Ивашка Потапова пасынок Тимошка } \\
\text { Иванов дватцати лет }\end{array}$ & $\begin{array}{l}\text { Двор пуст Ивана Патапова, у него сын Алек- } \\
\text { сей дву лет, сшел в мир безвесно в прошлом } \\
1701-\text { м году }\end{array}$ \\
\hline 2 & $\begin{array}{l}\text { Во дворе Ивашка Петров } 3 \text { детьми Ивашко, } \\
\text { Илейка, Федька осьмнатцати лет, у Ивашка де- } \\
\text { тей, Ефтюнка пяти лет, Петрунка трех лет, Васка } \\
\text { дву лет }\end{array}$ & $\begin{array}{l}\text { Во дворе Иван Петров, у него внучата, Аника } \\
\text { Ильин, Иван Федоров девяти лет, у Аники сын } \\
\text { Кирил трех лет }\end{array}$ \\
\hline 3 & $\begin{array}{l}\text { Во дворе Васька Обросимов, у него сын Еро- } \\
\text { фейка, у Ерофейка детей, Алешка осми лет, Гав- } \\
\text { рилко трех лет }\end{array}$ & $\begin{array}{l}\text { Во дворе Яков Васильев, у него дети, Иван, Фе- } \\
\text { дор, у Ивана сын Исак полутора году, у Федора } \\
\text { сын Андрей году }\end{array}$ \\
\hline 4 & $\begin{array}{l}\text { Во дворе Илейка Яковлев, у него брат Анд- } \\
\text { рюшка, у Илейки детей, Бориско двенатцати } \\
\text { лет, Федка трех лет, Гришка десяти лет, у Анд- } \\
\text { рюшки детей, Ивашко семи лет, Сенка трех лет, } \\
\text { у них же, у Илейки и у Андрюшки, племянник } \\
\text { Ивашко Лукин четырех лет да двуюродной их } \\
\text { брат Ивашка Леонтьев, у него детей Сенка осм- } \\
\text { натцати лет, Естефейка одиннатцати лет }\end{array}$ & $\begin{array}{l}\text { Во дворе Борис Ильин, у него дети, Дмитрей } \\
\text { дватцати лет, Сергей девяти лет } \\
\text { Во дворе Григорей Ильин, у него брат Федор } \\
\text { дватцати лет, у Григорья сын Илья семи лет } \\
\text { Во дворе Борис Ильин, у него сын Федор четы- } \\
\text { рех лет }\end{array}$ \\
\hline 5 & $\begin{array}{l}\text { Во дворе Карпунка Иванов, у него детей Сер- } \\
\text { гунка, Ефремка дватцати лет, Конка пяти лет, } \\
\text { Илейка дву лет }\end{array}$ & $\begin{array}{l}\text { Во дворе Сергей Карпов, у него брат Антипа } \\
\text { дватцати лет, у Сергея детей, Яков двенатцати } \\
\text { лет, Василей десяти лет, Андрей четырех лет }\end{array}$ \\
\hline 6 & $\begin{array}{l}\text { Во дворе Илейка Марков, у него сын Бориска } \\
\text { дватцати лет }\end{array}$ & - \\
\hline 7 & Во дворе Васка Софонов, у него брат Нестерко & - \\
\hline 8 & $\begin{array}{l}\text { Во дворе Якунка Василев, у него детей, Мишка } \\
\text { осми лет, Демка четырех лет, Ивашка дву лет }\end{array}$ & - \\
\hline 9 & - & $\begin{array}{l}\text { Во дворе Михайло Яковлев, у него сын Василей } \\
\text { девяти лет }\end{array}$ \\
\hline 10 & - & $\begin{array}{l}\text { Двор пуст Тимофея Иванова, у него детей, Тит } \\
\text { полутретья году, Иван полугоду, сшел в мир без- } \\
\text { весно в прошлом 1700-м году }\end{array}$ \\
\hline 11 & - & Во дворе Михайло Прокофьев \\
\hline 12 & - & Во дворе Иван Лукьянов \\
\hline 13 & - & $\begin{array}{l}\text { Во дворе Иван Левонтьев, у него сын Евсевей, у } \\
\text { Евсевья дети, Семен десяти лет, Дмитрей пяти } \\
\text { лет }\end{array}$ \\
\hline 14 & - & $\begin{array}{l}\text { Во дворе Федор Митрофанов, у него сын Аляк- } \\
\text { сей трех лет, у него же живет бобыль Алексей } \\
\text { Филипов дватцати лет, безпахотной, кормитца в } \\
\text { мире }\end{array}$ \\
\hline
\end{tabular}

Примечания. Источники: РГАДА. Ф. 1209. ЕД. хр. 14733. Л. 116 об.-117; Там же. Ф. 237. Оп. 1. Ч. 1. Ед. хр. 53. Л. 129 об. - 130. * - имена родственников или одних и тех же людей выделены полужирным шрифтом.

Notes. Sources: Russian State Archive of Ancient Acts (RGADA), f. 1209, dep. item 14733, 1. 116 r.-117; Ibid. f. 237, inv. 1, dep. item 53, 1. 129 r. - 130. * - names of relatives or the same people are given in bold. 


\section{СПИСОК ЛИТЕРАТУРЫ}

1. Анисимов, Е. В. Время петровских реформ /Е.В.Анисимов. - Л. : Лениздат, 1989. - 496 с.

2. Бакланова, Е. Н. Крестьянский двор и община на Русском Севере. Конец XVII - начало XVIII в. / Е. Н. Бакланова. - М. : Наука, 1976. - 221 с.

3. Башнин, Н. В. «Сшел в Сибирь»: миграция населения яренской вотчины Вологодского архиерейского дома в XVII в. / Н. В. Башнин // Российская история. - 2019. - № 1. - С. 127-145.

4. Башнин, Н. В. Дионисиево-Глушицкий монастырь и его архив в XV-XVII вв.: исследование и тексты / Н. В. Башнин. - М. ; СПб. : Альянс-Архео, 2016. - $1298 \mathrm{c}$.

5. Башнин, Н. В. Документы из архива Дионисиева Глушицкого монастыря: опись имущества и строений 1701 г., переписные книги вотчины 1702 г. / Н. В. Башнин // Вестник церковной истории. 2013. - № 3-4 (31-32). - С. 139-177.

6. Булыгин, И. А. Монастырские крестьяне России в первой четверти XVIII века / И. А. Булыгин. - М. : Наука, 1977. - 327 с.

7. Ведомости о монастырях 1723 г. // Архив Санкт-Петербургского института истории Российской академии наук (далее - Архив СПбИИ РАН). Кол. 238. - Оп. 2. - Картон 318. - Ед. хр. 2.

8. Ведомости о посевах и сборе хлеба в вотчинах Вологодского архиерейского дома и монастырей 1705 г. // Архив СПбИИ РАН. - Кол. 238. ОП. 2. - Картон 318. - Ед. хр. 1.

9. Ведомости о хозяйстве Вологодского архиерейского дома Св. Софии 1702-1703 гг. // Отдел рукописей Российской государственной библиотеки. -Ф. 354. - Ед. хр. 177. - Л. 1-654.

10. Виденеева, А. Е. О новом источнике по истории землевладения Ростовского архиерейского дома рубежа XVII-XVIII веков / А. Е. Виденеева // Уваровские чтения II. - М. : ИВФ Антал, 1994. - С. 90-92.

11. Водарский, Я. Е. Православные монастыри России и их роль в развитии культуры (XI - начало ХХ в.) / Я. Е. Водарский, Э. Г. Истомина. - М. : ИРИ РАН, 2009. - 546 с.

12. Говорова, А. Н. Житие преподобномученика Симона Воломского / А. Н. Говорова // Вестник церковной истории. - 2008. - № 4 (12). - С. 53-57.

13. Дмитриева, 3. В. Вытные и описные книги Кирилло-Белозерского монастыря XVI-XVII вв. / 3. В. Дмитриева. - СПб. : Дмитрий Буланин, 2003.$343 \mathrm{c}$.

14. Дмитриева, 3. В. О миграции населения монастырских вотчин в XVII в. / 3. В. Дмитриева, Н. В. Башнин // Актуальные проблемы аграрной истории Восточной Европы X-XXI вв.: источники и методы исследования : материалы XXXII сессии симпозиума по аграрной истории Восточной Европы. - Рязань : Ряз. гос. ун-т им. С.А. Есенина, 2012. - C. 113-123.

15. Завьялов, А. А. Вопрос о церковных имениях при императрице Екатрине II / А. А. Завьялов. СПб. : Тип. А. П. Лопухина, 1900. -400 с.

16. Никольский, Н. К. Описание рукописей Кирилло-Белозерского монастыря, составленное в XV веке / Н. К. Никольский. - СПб. : Синодальная тип., 1897. -328 с.

17. Окладная книга церквей Вологодской епархии 1724 г. // Архив СПбИИ РАН. - Кол. 238. - Оп. 2. Картон 318. - Ед. хр. 3.

18. Опись казны Вологодского архиерейского дома Св. Софии 1702 г. // Государственный архив Вологодской области. - Ф. 883. - Оп. 1. - Ед. хр. 238. Л. 1-112 об.

19. Опись строений и имущества Кирилло-Белозерского монастыря 1601 года: Комментированное издание / сост. 3. В. Дмитриева, М. Н. Шаромазов. СПб. : Петербургское востоковедение, 1998. - 380 с.

20. Переписные книги вологодских монастырей XVI-XVIII вв.: Исследование и тексты. -Вологда: Древности севера, 2011. - 495 с.

21. Переписные книги вотчин Вологодского архиерейского дома Св. Софии 1701-1702 гг. // Российский государственный архив древних актов. Ф. 237. - ОП. 1. - Ед. хр. 53. - Л. 1-253.

22. Переписные книги Кандалакшского Пречистенского монастыря и церкви Иоанна Предтечи села Кандалакша XVIII века / подгот. текстов и исслед. С. А. Никонов, Л. В. Пушкина. - М. ; СПб. : Альянс-Архео, 2019.- 304 с.

23. Покровский, И. М. Русские епархии в XVIXIX вв., их открытие, состав и пределы. Опыт церковно-исторического, статистического и географического исследования / И. М. Покровский. - Казань : Центральная тип., 1913.- Т. 2 (ХVIII в.). -892 с.

24. Полное собрание законов Российской империи с 1649 г. - СПб. : Тип. ІІ Отделения Собственной Его Императорского Величества Канцелярии, 1830. - T. V. - 1115 c.

25. Правила святых Вселенских соборов с толкованиями. - М. : Сибирская благозвонница, 2011. - $737 \mathrm{c}$.

26. Русское православие: вехи истории / науч. ред. А. И. Клибанов. - М. : Политиздат, 1989. - 719 с.

27. Седов, П. В. «Все-де ныне государево»: традиции и новации в церковной реформе Петра I / П. В. Седов // Феномен реформ на западе и востоке Европы в начале Нового времени (XVIXVIII вв.) : сб. ст. - СПб. : Изд-во Европейского университета в Санкт-Петербурге, 2013. - С. 122-142.

28. Соколова, Н. В. Описание церковно-монастырских владений в процессе секуляризации начала XVIII в.: Опыт реконструкции (на материалах 
Нижегородского уезда) / Н. В. Соколова // СевероЗапад в аграрной истории России : межвуз. темат. сб. науч. тр. - Калининград : Рос. гос. гуманит. ун-т им. Иммануила Канта, 2008. - С. 44-60.

29. Хозяйственные книги Вологодского архиерейского дома Святой Софии XVII - начала XVIII в. / сост. Н. В. Башнин. - М. ; СПб. : Альянс-Архео, 2018. $-896 \mathrm{c}$.

30. Черкасова, М. С. Государственная ревизия вологодских монастырей в начале XVIII в. / М. С. Черкасова // Управление и экономика: опыт, теория, практика : материалы науч. конф. (г. Вологда, 10-11 апр. 2009 г.). - Вологда : СЗАГС, 2009. - С. 132-145.

31. Черкасова, М. С. К характеристике монастырских архивов России XVI-XVII вв. (Ч. 2) / М. С.Черкасова // Археографический ежегодник за 2004 г. М. : Наука, 2005. - С. 30-45.

32. Черкасова, М. С. Об эволюции комплекса монастырских описных книг в XV-XVIвв. / М. С. Черкасова // VII Ушаковские чтения : сб. науч. ст. - Мурманск : МГПУ, 2011.-С. 206-218.

33. Черкасова, М. С. Переписная книга Устюжской епархии 1696/97 г.: из истории практического архивоведения на севере России в конце XVII в. / М. С. Черкасова // Вестник РГГУ. Серия: Исторические науки. Историография, источниковедение, методы исторических исследований. 2011. - № 12 (74) / 11. - С. 117-130.

34. Шамина, И. Н. Документы по истории Григориева Пельшемского монастыря XVII - начала XVIII века / И. Н. Шамина // Вестник церковной истории. - 2011. - № 3-4 (23-24). - С. 30-63.

35. Шамина, И. Н. Опись имущества вологодского Павлова Обнорского монастыря 1701-1702 годов / И. Н. Шамина // Вестник церковной истории. 2010. - № 1-2 (17-18). - С. 17-107.

36. Шамина, И. Н. Переписная книга Успенской Семигородней пустыни Вологодского уезда 1702 г. / И. Н. Шамина // Вестник церковной истории. - 2017. - № 1-2 (45-46). -С. 99-111.

37. Шамина, И. Н. Переписные книги коломенских Спасо-Преображенского, Голутвина, Бобренева и Брусенского монастырей 1701 г. / И. Н. Шамина // Вестник церковной истории. - 2017. - № 3-4 (47-48). - C. 96-226.

38. Шамина, И. Н. Преподобный Иннокентий Комельский и основанный им монастырь / И. Н. Шамина // Вестник церковной истории. - 2009. - № 1-2 (13-14).-C. 26-99.

\section{REFERENCES}

1. Anisimov E.V. Vremya petrovskikh reform [Time of Peters Reforms]. Leningrad, Lenizdat, 1989. $496 \mathrm{p}$.
2. Baklanova E.N. Krestyanskiy dvor $i$ obshchina na Russkom Severe. Konets XVII-nachalo XVIII v. [Peasant Yard and Community in the Russian North. Late $17^{\text {th }}-$ Early $18^{\text {th }}$ Century]. Moscow, Nauka Publ., 1976. 221 p.

3. Bashnin N.V. «Sshel v Sibir»: migratsiya naseleniya yarenskoy votchiny Vologodskogo arkhiereyskogo doma v XVII v. ["Went to Siberia": Migration of the Population of the Yarensky Patrimony of the Vologda Bishops House in the $17^{\text {th }}$ Century]. Rossiyskaya istoriya [Russian History], 2019, no. 1, pp. 127-145.

4. Bashnin N.V. Dionisievo-Glushitskiy monastyr $i$ ego arkhiv $v X V-X V I I v v$ : : issledovanie $i$ teksty [Dionysian-Glushitsky Monastery and Its Archive in $15^{\text {th }}-17^{\text {th }}$ Centuries: Research and Texts]. Moscow, Saint Petersburg, Alyans-Arkheo Publ., 2016. $1298 \mathrm{p}$.

5. Bashnin N.V. Dokumenty iz arkhiva Dionisieva Glushitskogo monastyrya: opis imushchestva i stroeniy 1701 g., perepisnye knigi votchiny 1702 g. [Documents from the Archives Dionissiev Glushitskii Monastery: An Inventory of the Property and Buildings 1701, Census Books Fiefdoms 1702]. Vestnik tserkovnoy istorii [Herald of Church History], 2013, no. 3-4 (31-32), pp. 139-177.

6. Bulygin I.A. Monastyrskie krestyane Rossii $v$ pervoy chetverti XVIII veka [Monastic Peasants of Russia in the First Quarter of the $18^{\text {th }}$ Century]. Moscow, Nauka Publ., 1977. 327 p.

7. Vedomosti o monastyryakh $1723 \mathrm{~g}$. [Statements About Monasteries in 1723]. Arkhiv Sankt-Peterburgskogo instituta istorii Rossiyskoy akademii nauk [Archive of the St. Petersburg Institute of History of the Russian Academy of Sciences], col. 238, inv. 2, cart. 318, dep. item 2 .

8. Vedomosti o posevakh i sbore khleba $\mathrm{V}$ votchinakh Vologodskogo arkhiereyskogo doma i monastyrey 1705 g. [Statements About Crops and Collecting Bread in Patrimony of the Vologda Bishops House and Monasteries in 1705]. Arkhiv SPbII RAN [Archive of the St. Petersburg Institute of History of the Russian Academy of Sciences], col. 238, inv. 2, cart. 318, dep. item 1.

9. Vedomosti o khozyaystve Vologodskogo arkhiereyskogo doma Sv. Sofii 1702-1703 gg. [Statements About the Economy of the Vologda Bishops House of St. Sofia 1702-1703]. Otdel rukopisey Rossiyskoy gosudarstvennoy biblioteki [Department of Manuscripts of the Russian State Library], f. 354, dep. item 177, 1. 1-654.

10. Videneeva A.E. O novom istochnike po istorii zemlevladeniya Rostovskogo arkhiereyskogo doma rubezha XVII-XVIII vekov [About the New Source on the History of Land Ownership of the Rostov Bishops House of the Turn of $17^{\text {th }}-18^{\text {th }}$ Centuries]. 
Uvarovskie chteniya II [Uvarov Readings II]. Moscow, IVF Antal Publ., 1994, pp. 90-92.

11. VodarskiyYa.E., Istomina E.G. Pravoslavnye monastyri Rossii i ikh rol v razvitii kultury (XInachalo $X X$ v.) [Orthodox Monasteries of Russia and Their Role in the Development of Culture $\left(11^{\text {th }}-\right.$ Early $20^{\text {th }}$ Century)]. Moscow, IRI RAN, 2009. $546 \mathrm{p}$.

12. Govorova A.N. Zhitie prepodobnomuchenika Simona Volomskogo [The Life of the Monk Simon Volomsky]. Vestnik tserkovnoy istorii [Herald of Church History], 2008, no. 4 (12), pp. 53-57.

13. Dmitrieva Z.V. Vytnye i opisnye knigi KirilloBelozerskogo monastyrya XVI-XVII vv. [Tax and Inventory Books of the Kirillo-Belozersky Monastery of the $16^{\text {th }}-17^{\text {th }}$ Centuries]. Saint Petersburg, Dmitriy Bulanin Publ., 2003. 343 p.

14. Dmitrieva Z.V., Bashnin N.V. O migratsii naseleniya monastyrskikh votchin $\mathrm{v}$ XVII v. [On the Migration of the Population of Monastic Fiefdoms in the $17^{\text {th }}$ Century]. Aktualnye problemy agrarnoy istorii Vostochnoy Evropy X-XXI vv.: istochniki $i$ metody issledovaniya: materialy XXXII sessii simpoziuma po agrarnoy istorii Vostochnoy Evropy [Current Problems of Agricultural History of Eastern Europe in the $10^{\text {th }}-21^{\text {st }}$ Centuries: Sources and Research Methods. Proceedings of the $32^{\text {nd }}$ Session of the Symposium on Agricultural History of Eastern Europe]. Ryazan, Ryazanskiy gosudarstvennyy universitet im. S.A. Esenina, 2012, pp. 113-123.

15. Zavyalov A.A. Vopros o tserkovnykh imeniyakh pri imperatritse Ekatrine II [Question of Church Estates Under Empress Catherine II]. Saint Petersburg, Tipografiya A. P. Lopukhina, 1900. 400 p.

16. Nikolskiy N.K. Opisanie rukopisey KirilloBelozerskogo monastyrya, sostavlennoe v XV veke [Description of Manuscripts of the Kirillo-Belozersky Monastery Compiled in the $15^{\text {th }}$ Century]. Saint Petersburg, Sinodalnaya tipografiya, 1897. 328 p.

17. Okladnaya kniga tserkvey Vologodskoy eparkhii 1724 g. [Salary Book of Churches of the Vologda Diocese 1724]. Arkhiv SPbII RAN [Archive of the St. Petersburg Institute of History of the Russian Academy of Sciences], col. 238, inv. 2, cart. 318, dep. item 3.

18. Opis kazny Vologodskogo arkhiereyskogo doma Sv. Sofii $1702 \mathrm{~g}$. [Inventory of the Treasury of the Vologda Bishops House of St. Sofia 1702]. Gosudarstvennyy arhiv Vologodskoy oblasti [State Archive of Vologda Region], f. 883, inv. 1, dep. item 238. 1. 1-112r.

19. Opis stroeniy i imushchestva KirilloBelozerskogo monastyrya 1601 goda: Kommentirovannoe izdanie [Inventory of Buildings and Property of the Kirillo-Belozersky Monastery in 1601: Commented Edition]. Saint Petersburg, Peterburgskoe vostokovedenie Publ., 1998. 380 p.
20. Perepisnye knigi vologodskikh monastyrey XVI-XVIII vv.: Issledovanie i teksty [Inventory Books of Vologda Monasteries of $16^{\text {th }}-18^{\text {th }}$ Centuries: Research and Texts]. Vologda, Drevnosti severa Publ., 2011.495 p.

21. Perepisnye knigi votchin Vologodskogo arkhiereyskogo doma Sv. Sofii 1701-1702 gg. [Inventory Books of the Patrimonies of the Vologda Bishops House of St. Sofia of 1701-1702]. Rossiyskiy gosudarstvennyy arkhiv drevnikh aktov [Russian State Archive of Ancient Acts], f. 237, inv. 1, dep. item 53,1.1-253.

22. Perepisnye knigi Kandalakshskogo Prechistenskogo monastyrya i tserkvi Ioanna Predtechi sela Kandalaksha XVIII veka [Census Books of Kandalaksha Prechistensky Monastery and the Church of John the Baptist of Village Kandalaksha of $18^{\text {th }}$ Century]. Moscow, Saint Petersburg, AlyansArkheo Publ., 2019. 304 p.

23. Pokrovskiy I.M. Russkie eparkhii $v$ XVI$X I X v v$, ikh otkrytie, sostav i predely. Opyt tserkovnoistoricheskogo, statisticheskogo i geograficheskogo issledovaniya [The Russian Diocese in the $16^{\text {th }}-19^{\text {th }}$ Centuries, Their Discovery, Composition and Limits. Experience of Church Historical, Statistical and Geographical Research]. Kazan, Tsentralnaya tipografiya, 1913, vol. 2 (XVIII c.). 892 p.

24. Polnoe sobranie zakonov Rossiyskoy imperii $s 1649 \mathrm{~g}$. [Full Corpus of Russian Imperial Acts]. Saint Petersburg, Tipografiya II Otdeleniya Sobstvennoy Ego Imperatorskogo Velichestva Kantselyarii, 1830, vol. $5.1115 \mathrm{p}$.

25. Pravila svyatykh Vselenskikh soborovs tolkovaniyami [Rules of Saint Oecumenical Councils with Explanations]. Moscow, Sibirskaya blagozvonnitsa Publ., 2011. 737 p.

26. Russkoe pravoslavie: vekhi istorii [Russian Orthodox: Markers of History]. Moscow, Politizdat, 1989. 719 p.

27. Sedov P.V. «Vse-de nyne gosudarevo»: traditsii i novatsii v tserkovnoy reforme Petra I [All Is Now to Tsar: Tradition and Innovation in Peters I Reform]. Fenomen reform na zapade i vostoke Evropy $v$ nachale Novogo vremeni (XVI-XVIII vv.): sb. st [Phenomenon of Reforms in the West and East of Europe at the Beginning of the Modern Age $\left(16^{\text {th }}-\right.$ $18^{\text {th }}$ Centuries). Collection of Articles]. Saint Petersburg, Izd-vo Evropeyskogo universiteta v SanktPeterburge, 2013. pp. 122-142.

28. Sokolova N.V. Opisanie tserkovnomonastyrskikh vladeniy $\mathrm{v}$ protsesse sekulyarizatsii nachala XVIII v.: Opyt rekonstruktsii (na materialakh Nizhegorodskogo uezda) [Description of Churche and Monastery Lands During Secularization in the Early $18^{\text {th }}$ Century: Experience of Reconstruction on Materials of Nigny Novgorod Uyezd]. Severo-Zapad v agrarnoy 
istorii Rossii: mezhvuz. temat. sb. nauch. tr. [North-West in the Agrarian History of Russia. Interuniversity IssueRelated Collection of Scientific Works]. Kaliningrad, Rossiyskiy gosudarstvennyy gumanitarnyy universitet im. Immanuila Kanta, 2008, pp. 44-60.

29. Bashnin N.V., ed. Khozyaystvennye knigi Vologodskogo arkhiereyskogo doma Svyatoy Sofii XVII-nachala XVIII v. [Economy Books of Vologda Archbishop House of St Sofiya of the $17^{\text {th }}-$ Early $18^{\text {th }}$ Century]. Moscow, Saint Petersburg, AlyansArkheo Publ., 2018. 896 p.

30. Cherkasova M.S. Gosudarstvennaya reviziya vologodskikh monastyrey v nachale XVIII v. [State Control of Vologda Monasteries in the Early $18^{\text {th }}$ Century]. Upravlenie $i$ ekonomika: opyt, teoriya, praktika: materialy nauch. konf. (g. Vologda, 10-11 apr. 2009 g.) [Management and Economy: Experience, Theory, Practice. Proceedings of the Scientific Conference (Vologda, April 10-11, 2009)]. Vologda, SZAGS, 2009, pp. 132-145.

31. Cherkasova M.S. K kharakteristike monastyrskikh arkhivov Rossii XVI-XVII vv. (Ch. 2) [Toward the Characteristic of Monastery Archives in Russia in the $16^{\text {th }}-17^{\text {th }}$ Centuries]. Arkheograficheskiy ezhegodnik za $2004 \mathrm{~g}$. [Archaeographic Yearbook for 2004]. Moscow, Nauka Publ., 2005, pp. 30-45.

32. Cherkasova M.S. Ob evolyutsii kompleksa monastyrskikh opisnykh knig v XV-XVI vv. [About the Evolution of the Complex of Monastery Inventory Books in the $15^{\text {th }}-16^{\text {th }}$ Centuries]. VII Ushakovskie chteniya: sb. nauch. st. [Ushakov Readings. Collection of Scientific Articles]. Murmansk, 2011, pp. 206-218.

33. Cherkasova M.S. Perepisnaya kniga Ustyuzhskoy eparkhii 1696/97 g.: iz istorii prakticheskogo arkhivovedeniya na severe Rossii v kontse XVII v. [Inventory Book of Ustug Eparchy 1696/97:About History of Practical Archive in Russian North in the End of $17^{\text {th }}$ Century]. Vestnik RGGU. Seriya: Istoricheskie nauki. Istoriografiya, istochnikovedenie, metody istoricheskikh issledovaniy, 2011, no. 12 (74)/11, pp. 117-130.

34. Shamina I.N. Dokumenty po istorii Grigorieva Pelshemskogo monastyrya XVII - nachala XVIII veka [Documents by History of Grigoriev Pelshemskii Monastery in $17^{\text {th }}-$ Early $18^{\text {th }}$ Century]. Vestnik tserkovnoy istorii [Herald of Church History], 2011, no. 3-4 (23-24), pp. 30-63.

35. Shamina I.N. Opis imushchestva vologodskogo Pavlova Obnorskogo monastyrya 1701-1702 godov [Inventory Book of Vologda Pavlov Obnorskii Monastery 1701-1702]. Vestnik tserkovnoy istorii [Herald of Church History], 2010, no. 1-2 (17-18), pp. 17-107.

36. Shamina I.N. Perepisnaya kniga Uspenskoy Semigorodney pustyni Vologodskogo uezda $1702 \mathrm{~g}$. [Inventory Book of Uspenskaya Semigorodnyaya Pustyn in Vologda Region 1702]. Vestnik tserkovnoy istorii [Herald of Church History], 2017, no. 1-2 (45-46), pp. 99-111.

37. Shamina I.N. Perepisnye knigi kolomenskikh Spaso-Preobrazhenskogo, Golutvina, Bobreneva i Brusenskogo monastyrey $1701 \mathrm{~g}$. [Census Books of the Kolomna Spaso-Preobrazhensky, Golutvin, Bobrenev and Brusensk Monasteries of 1701]. Vestnik tserkovnoy istorii, 2017, no. 3-4 (47-48), pp. 96-226.

38. Shamina, I. N. Prepodobnyy Innokentiy Komelskiy i osnovannyy im monastyr [St. Innokentii of Komela and His Monastery]. Vestnik tserkovnoy istorii, 2009, no. 1-2 (13-14), pp. 26-99.

\section{Information About the Author}

Nikita V. Bashnin, Candidate of Sciences (History), Senior Researcher, Saint Petersburg Institute of History of the Russian Academy of Science, Petrozavodakaya St, 7, 197110 Saint Petersburg, Russian Federation, nvbashnin@gmail.com, https://orcid.org/0000-0003-2209-8750

\section{Информация об авторе}

Никита Викторович Башнин, кандидат исторических наук, старший научный сотрудник Санкт-Петербургского института истории РАН, ул. Петрозаводская, 7, 197110 г. Санкт-Петербург, Российская Федерация, nvbashnin@gmail.com, https://orcid.org/0000-0003-2209-8750 